Note: this is a postprint version of an essay published in Nineteenth-Century Theatre and Film 40:1 (2013) http://dx.doi.org/10.7227/NCTF.40.1.3

\title{
Jewishness and the Covent Garden OP War: Satiric Perceptions of John Philip Kemble ${ }^{\mathrm{i}}$
}

Between 6 and 14 October 1809 Jewish boxers were employed by the management of Covent Garden theatre to bring an end to the Old Price (or OP) war, riots against increased prices, architectural redistribution, and the hiring of foreign actors which had raged nightly within the theatre since it had reopened on 18 September $1809 .{ }^{\text {ii }}$ Each night of the OP war numerous disgruntled theatregoers paid to enter the theatre with the intention of shouting, dancing, singing, playing instruments, waving placards, and making speeches. ${ }^{\text {iii }}$ In short to do anything but observe the planned entertainments. Despite these protests audience numbers remained buoyant with theatregoers seemingly eager to witness and to contribute to this enduring conflict between spectacle and counter-spectacle. ${ }^{\text {iv }}$ The OP war is therefore an important event in the history of early-nineteenth century protest, during which various historical actors elided form and argument as a means of defending customary rights. ${ }^{\mathrm{v}}$

This significance is attested by the contemporary response of London's print media. Metropolitan satirical printers, from Samuel Fores in the respectable West End to Thomas Tegg on Cheapside, responded vigorously in support of the rioters, displaying in print a dissatisfaction towards the imposition by the management upon freedom of expression, tradition, and the common law rights of the 'Freeborn Englishman'. The written press also responded to these events, metropolitan newspapers in particular contained daily reports concerning Covent Garden theatre. These media rarely however took overt editorial positions either resolutely for or against the rioters. ${ }^{\mathrm{vi}}$ Instead newspapers catered for diverse metropolitan and provincial opinion(s) through reports both from the theatre and the Bow 
Street magistrates, letters from their readers, letters from the management, and advertisements. ${ }^{\text {vi }}$

As we shall see the discourses these satires, letters and reports generated concerned themselves with the Jewish phase of the riots far beyond mid-October 1809, stretching both its temporal and spatial meaning along the way. It is therefore the phenomenon of this understudied episode within the OP conflict that this essay seeks to tease out, in doing so exploring the correspondence between theatrical disputes and broader cultural trends in the late-Georgian metropolis. But this essay also contains a more particular focus, namely on how an image of John Philip Kemble, lead actor and co-owner of Covent Garden Theatre, was constructed through the lens of OP and Jewishness. It was Kemble who was supposed to have hired pugilists to repel the OPs (as the supports of Old Prices were known), and this essay will begin with by detailing the rapid and voluminous response of London's newspapers to the introduction of Jewish pugilists into Covent Garden theatre. The nature of the Jewish stereotype forms the second component of the present essay, a necessary backward chronological step whose insights illuminate the traditions from which stereotyping in the early-nineteenth century were drawn. Finally, I will analyse the representational strategies used in single-sheet satirical prints produced by London's print-shops in response to the Jewish phase of the OP war, and the deployment of the Jewish stereotype found therein. What this study reveals is the significance of this short phase of the OP war on how the conflict was narrated in toto. By affixing a Jewish characterisation to Kemble, graphic satires revealed the grander 'logic' of his actions, placing them into a wider narrative of racial conspiracy which spilled beyond the physical boundaries of theatric space into the mental universe of earlynineteenth century metropolitan London.

\section{I: 'Kemble's Desperate Band'}


In a letter to the Morning Chronicle dated Wednesday, 18 October 1809 one James Powell of 'Grove-place, Camden Town' asked:

How did it happen that they [the Jewish pugilists] suddenly collected together, not only to support the Proprietors in their attempted imposition, but actually to beat every person they could get at who manifested disapprobation, and that too for several successive nights? And how it had happened, that since the publication of Mr. Bish's and my letter, they have so suddenly ceased attendance? ? vii $^{\text {iii }}$

Powell's letter refers to correspondence between Thomas Bish, the noted lottery entrepreneur, and various metropolitan newspapers. In these letters Bish claimed to have uncovered evidence of a conspiracy implicating the Covent Garden Theatre management in hiring 'Jews of the lowest description' to repel the protestations of the OPs. ${ }^{\text {ix }}$ As Bish wrote on 11 October: I must remark, that I saw him myself, and can bring 20 respectable persons (who also saw him) to prove that [Dan] Mendoza [the noted pugilist] has for several days past distributed a considerable number of Free Admissions to Covent Garden Theatre, to such persons as were more likely to break than keep the peace. ${ }^{\mathrm{x}}$

Bish was a hero of the OPs, lauded for not hiding behind pseudonyms in his public proclamations: a placard hoisted in Covent Garden Theatre on 13 October read "BISH, the Detector of Fraud v MENDOZA, the Leader of hired Pugilists". xi

Powell's letter also confirms that by 18 October Jewish pugilists had all but ceased their activity against the OPs. The Times noted on 20 October that after some loud vociferation of 'Off! Off! Off!' towards the conclusion of the play '[w]e heard no more of the boxing Jews, and, therefore, it appeared that their subsidizing aid was withdrawn'. ${ }^{\text {xii }}$ In all 
likelihood these elements had effectively dispersed after the previous Saturday's performance (14 October), upon which it was reported by The Morning Chronicle that:

Certain Jews have not been so offensively pushed forward by the Proprietors for the last two nights; but the Police have been equally active. ${ }^{\text {xii }}$

This Jewish phase of the OP war then lasted little more than seven nights (the theatre did not open on Sundays). It is then an indication of the opprobrium caused that newspaper responses to those seven nights are vastly disproportionate to the temporal significance of this period with respect to the riots as a whole. ${ }^{\text {xiv }}$ During the weeks that followed correspondents with newspapers continued to display their distaste for these 'Jew' pugilists. This was perhaps fuelled by continued discussion of the alleged conspiracy. Bish repeated his charge on October $19^{\text {th }}$, this time more strongly worded and containing fresh accusations:

I have to inform you, Sir, that at the house of a Jew Pastrycook in Duke's Place, Mendoza distributed, I may safely say, hundreds of Free Admissions to Covent Garden Theatre. The door of the Pastrycook's house was more crowded on the occasion than the doors of the Theatre, and however ignorant the Managers may pretend to be of such Orders having been given, they must (or ought to) have known, that those Orders daily issued by Mendoza were admitted at the Theatre. $^{\mathrm{xv}}$

Another letter published days before the Royal Jubilee foregrounded this phase of the OP war by stating that the liberty of the press 'is the only resource left for poor John Bull. It may be called the bugle-horn of his grievances - a bugle, that all the Jews, prize-fighters, and thieftakers cannot silence'. ${ }^{\mathrm{xi}}$ Elsewhere a subscriber in late-October to the 'SUBSCRIPTION for the assistance of PERSONS considered UNJUSTLY PROSECUTED by the PROPRIETORS and MANAGERS of COVENT GARDEN THEATRE' contributed money under the 
pseudonyms 'A Christian recovering from the wrath of a Jew' and 'A Bonus for Aitches, and Jew be-iying'. ${ }^{\text {vii }}$ Here Jewish pugilists are remembered as violent suppressors of Christian OPs, with Kemble - invoked by the second subscriber through Kemble's much ridiculed two syllable pronunciation of 'aches' - their collaborator. Another anonymous subscriber, this time from late November, signed himself as 'A Friend to the Injured - to defend them against the insolence of Jews, and the impertinence of Vagrants'. ${ }^{x i i i}$ The OPs here are both in recuperation and under active assault from both 'Jews' and 'Vagrants': the latter group including, through a subtle allusion to the 1737 Licensing Act, actors such as Kemble. ${ }^{\text {xix }}$

Such was the ferocity with which anti-Jewish rhetoric was remembered that a $7 \mathrm{~s}$. pamphlet entitled A VINDICATION of the JEWS was published towards the end of the Jewish phase of the OP war. The text, written by Thomas Witherby and sold by, among others, Hatchard's of Piccadilly, was an '[a]ttempt to remove Prejudices concerning the Jewish Nation'. ${ }^{x}$ Indeed as the pseudonymous COSMOPOLITE articulated in the Morning Chronicle, these prejudices were widespread:

I cannot see why the Jews should be singled out from the rest of the disorderly [...] Is it then not prejudice, to call in question some of the most honourable characters of the Jews, on account of a few hired fighting fellows. Surely we live in an age of reason; let us not run back from civilization to refer to the blood-stained pages of the dark ages of persecution; let us not be unjust to a Jew, for no other reason than he being a Jew. ${ }^{\text {xxi }}$

Subscribers to the aforementioned subscription list also indicated a willingness to diffuse this heightened anti-Jewish rhetoric - one listing his or herself as 'A Jew and an Enemy to imposition', ${ }^{x x i i}$ a second as 'A few independent Jews, and no hired Ruffians'. ${ }^{x i i i}$

If public discussions of London's Jewish communities in the newspaper press are one barometer of continued anti-Jewish discourse after the Jewish phase of the riots, then so too is 
the fixation of placard wavers inside Covent Garden theatre towards their former Jewish belligerents. 'No hired Jews' was a regular cry, ${ }^{\text {xxiv }}$ as were, according to newspaper reports, more creative contributions taking the form of ditties and intertextual rhymes:

The Drama's laws are now abused,

And KEMBLE's desperate band

Of hired Ruffians - ragged Jews,

With him go hand in hand. ${ }^{\mathrm{xxv}}$

Jockey of Hereford,

Be not over bold,

For Israel thy servant

Is bought and sold. ${ }^{\mathrm{xxvi}}$

Tellingly, the disquiet caused by this phase of the riots led to disproportionate reflections on purported Jewish activities in the theatre not only over the ensuing days but also over the ensuing months. By November the OPs had a new cause celebre - the arrest of the radical barrister Henry Clifford by James Brandon (the doorman of Covent Garden Theatre), and the former's subsequent acquittal and counter-suit. At this time Kemble et al curiously combined official conciliation (notably on OP demands that the theatre be considered public rather than private in character) with a resumption of heavy-handed tactics. And at the merest sign of Jewish involvement, OPs eagerly revived earlier motifs. On 11 November, for example, a scuffle in the theatre between Abraham Hart Braham and Michael Thompson (both residents of Villiers Street) saw both men taken before the Bow Street Magistrates and the former 'ordered to find bail, which he procured'. On the same day the report into this incident was published, Thompson wrote to The Times claiming to have attended Covent Garden theatre only after having seen the letter of concession from the management in various metropolitan 
newspapers. ${ }^{\text {xxvii }}$ However, he writes, '[t]he appearance of the pit, on my entering, convinced me it could not be the intention of the Proprietors to offer any conciliatory terms'. That 'appearance', he continues, was as he had feared - one of violent and brutal men. It is here Thompson invokes previous 'Jew' motifs, writing that '[t]he man from whom I received the blow [Braham], would positively have sworn I struck him first'.

Thompson's implication is that for Braham oaths were meaningless. This was no isolated commentary, controversy over non-Christians taking oaths was long-standing and widespread: the Jewish Naturalisation Act (1753) fell over the perceived incompatibility between English law and non-Christian oath taking, hostility toward Christian dissenters were - as we shall see - often made on similar grounds, and the bitter debates of the late-1820s over Catholic Emancipation were suffused with discussions of oaths and dissent. ${ }^{\text {xxviii }}$ It comes as no surprise then that Thompson finishes his letter by reminding the reader that Braham is ' $a$ Jew'.

\section{II: The Jewish Stereotype}

This long-tail of anti-Jewish rhetoric during the months of the OP war is perhaps not unexpected in either its extent or in the diversity of its outlets. Indeed this 'pugilistic tribe' provoked OPs (and seemingly a wide cross-section of gentleman metropolitans) into a momentary defence of custom that was ferocious, caustic, and viciously xenophobic in character. ${ }^{\text {xxix }}$ Yet this Jewish activity also fitted into a tradition of caricaturing 'Jewishness' which remained alive and well at the beginning of the nineteenth-century. There is no space here to explore this phenomenon at any length - I direct the reader in search of greater exposition to excellent work on the subject by Matthew Biberman, Frank Felsenstein, Dana Rabin, Michael Ragussis, and Jerry White - and so a summative account must suffice. ${ }^{\mathrm{xx}}$ 
In the late-eighteenth and early-nineteenth centuries Jewish populations were a significant aspect of the metropolitan diaspora, particularly in the multi-racial East End of London where Jewish immigrant communities were second only to Irish communities in social prominence. ${ }^{\mathrm{xxi}}$ Experience of Jewish communities did not however prevent the Jewish stereotype being particularly prone to irrational construction in late-Georgian urban discourse. In sum, Shylock and The Wandering Jew remained acceptable representations of Jewishness. ${ }^{\text {xxxii }}$ As Frank Felsenstein notes with respect to this phenomenon, Anglophonic folk and oral traditions were susceptible to corruption in urban spaces as a consequence of migration from the country to the metropolis. ${ }^{x x i i i}$ Therefore without a cumulative discourse of Jewishness to draw upon and as (a few scandals aside) the urban Jewish community were largely quiet and unassuming, Londoners could more readily accepted crude readings of ancient quasi-biblical traditions as 'facts' of Jewish character when such 'facts' were required. This made the Jewish stereotype in the capital hugely malleable and fraught with inconsistency at the turn of the nineteenth century. Indeed at this apparent point of rhetorical transition, ${ }^{\text {xxiv }}$ 'Jews' were perceived as both clannish and individualistic; loyal Britons and of a nation apart; cowardly and peaceable. Precedents for all these contradictory behaviours could be read into ancient narratives, but arching over all these was one simple 'truth' - the Jewish could not be trusted for they betrayed Jesus.

Such was the status of the Jewish stereotype in England's metropolis at the time of the OP war, ${ }^{\mathrm{xxx}}$ a protean characterisation observable in contemporary graphic satire. In for instance THE LOYAL JEW_and FRENCH SOLDIER or BEARD against WHISKERS!! (William Holland, 1803) a comic Ashkenazi vows to protect John Bull and King George (as well as the synagogue) against French invaders. ${ }^{\text {xxxvi }}$ He vows to do so by lending the King money, by the best means at his disposal. Without question this dynamic played into longstanding stereotypes of the Jew and usury, but the critique here is light at best: largely 
reflecting as opposed to challenging an urban and social reality. ${ }^{\mathrm{xxxvii}}$ And yet in the same year we find in prints such as EASIER to say, than to $\underline{d o}$ ! [Figure 1] the image of London's Jewish residents as loyal bankers competing with representations of this group as neutral (and hence disloyal) financiers. Upon seeing Napoleon's plans for European domination, the elderly Jewish male in EASIER to say states "I tink if I lend a little more monish at TurtyPerShent, it will soon annihilate dem." ${ }^{\text {xxviii }}$ A sense of clannish profiteering is then foregrounded, reiterating rhetoric seen in Woodward's earlier (though ever popular) Eccentric Excursions (1796) where a Jewish male holding a newspaper points only to a headline reading 'Stock'. ${ }^{\text {xxix }}$ In a slightly later print entitled SOLOMON in all his GLORY!! [Figure 2], 'a Jew' becomes something very different again. ${ }^{\mathrm{xl}}$ This time we see a Jewish male (identified by his name, his beard, and his nose) who is meek, his wealth his weakness when approached by London's courtesans. The man is thus emasculated, fitting squarely on this occasion within the 'Jewsissy' trope. ${ }^{\text {xli }}$

The Jewish stereotype was then one ripe for use and reuse when events in Covent Garden theatre turned on 6 October 1809; one whose malleability when applied to graphic satire both supports and contradicts scholarly metanarratives of changing attitudes towards Jewish communities in the Georgian metropolis. In particular, graphic OP narratives adapted the 'Jew' stereotype in three observable directions. First, Jewishness was equated with inherently clannish and violent behaviour; second, the Jewish 'type' was shown to be nonand, moreover, supra-racial; and third, Jewish actions were deemed to be subversive of custom and the common law. In what follows we shall see how this reconfiguration of the ancient Jewish type was applied in satirical prints to John Philip Kemble both during and beyond the Jewish phase of the OP war; a representative construction chosen for its readability, saleability and interoperability with a conflict whose ideology had crossed far beyond the threshold of Covent Garden theatre. 


\section{III: The Battle of Covent Garden Theatre}

On 21 October 1809 news reached as far as the Edinburgh published Caledonian Mercury that a notable mock handbill had circulated Covent Garden Theatre on 16 October. ${ }^{\text {xlii }}$ This bill purported to advertise forthcoming events at the theatre and was met with acclaim by the OPs. Significantly it concluded by calling John Philip Kemble 'Mr JEW KEMBLE'. This was a decisive act of rhetorical realignment which recast the relationship between Kemble and the Jewish pugilists from one of employer and employees to clannish conspirators. Given the confidence of this satire it is worth asking on what grounds it rested, and here we can reach to satirical prints for a glimpse at those foundations.

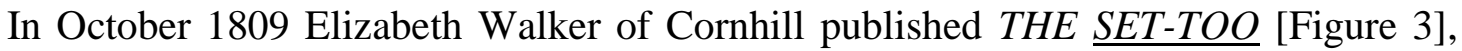
the first graphic satire which appears outwardly a direct response to the Jewish phase of the OP war. ${ }^{\text {xliii }}$ In this print a cut and bruised 'Old Price' stands tall (with support from John Bull) against a toned and muscular John Kemble. The latter resembles in type the famed Jewish boxers of the day such as Dutch Sam and Dan Mendoza, showmen implicated in a conspiracy against the OPs. Disgusted at the actions of the management in setting up a contest stacked in favour of innovation, 'Old Price' (like the real-life protesters he symbolises) refuses to go down, refuses to go away, refuses to be silenced.

Logic says that this is a print from the Jewish phase of the OP war, and yet in actuality the design pre-dates this phase of the riot. The publication line for Walker's print may with deliberate imprecision state 'October 1809 ', but its sub-title - 'fought with unabated vigour for nine rounds \& yet undecided Oct. 6 1809' - dates its inception to before the Jewish phase of the riots. Thus although the print may suggest that Kemble and Old Price had already 'fought with unabated vigour for nine rounds', in reality the violence reached its peak when 
the print was published rather than when the print was conceived. ${ }^{\text {xliv }}$ Indeed as The Times reported on 7 October 1809 the previous night at Covent Garden theatre had been remarkable for the 'pugilistic contests' therein. 'On the dropping of the curtain', their correspondent continued, 'the audience in the Pit did not sit down, as usual, to rest, but, by way of variety, cuffed each other until it rose again.' ${ }^{x l v}$

The fact that THE $\underline{\text { SET-TOO }}$ does not report the Jewish phase of the riots, but rather formed part of the discourse of this phase by an accident of timing, is made all the more ironic by future prints which made increasingly explicit the physiognomic connections between Dan Mendoza and John Philip Kemble. KILLING No MURDER: As Performing at the Grand National Theatre [Figure 4] is one such print, its title derived from a Cruikshank-Johnston print published the previous month which satirised the infamous duel between George Canning and Lord Castlereagh fought on 21 September 1809 on Putney Heath. If the title of the former design granted it by association some contemporary cache, its design achieved different purposes. The action therein centres on a subhuman rabble beating and robbing a well-dressed OP. The group are viciously caricatured, for while largely similar in possessing a racial signifier - a large, drooping nasal silhouette - their persons lack the respectability of form: one assailant displays bulging, ferocious eyes; three reveal sharp and pointed teeth within gaping, animalistic mouths; many carry crude and barbaric weaponry; most possess angular and irregular faces devoid of classical symmetry; and all exhibit sartorial distress, be that through irregular hats or dirty and worn clothing.

These men are the 'Israelitish ruffians' London's newspapers reported upon during the earlier Jewish phase of the riots, and their presence indicates that instead of representing events in Covent Garden Theatre at the time of publication (November) the print memorialises events of early October, revisiting them through another live controversy. Why was this strategy chosen? One clue can be found in the deployment here of Mendoza-cum- 


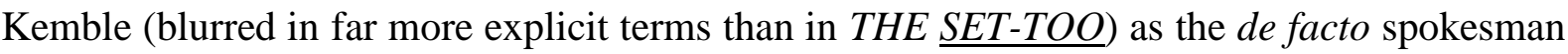
for the Jewish pugilists. With a knee pressed against the chest of a terrified OP, Mendozacum-Kemble raises a fist to his trapped opponent and declares 'Down down to $\mathrm{H}-\mathrm{l}$ with all O.P.'s \& say t'was Dan that sent the [sic] there'. His fitted jacket, fine ruffle, and groomed hair exhibit social status, offering (if we rotate the image 45 degrees) a fascinating line of symmetry with the cudgel-wielding attacker at the focal point of the scene.

In KILLING no MURDER then Kemble is blurred twice - once with a noted Jewish boxer purported to have organised the resistance to the OPs in early-October, and a second time with the multifarious stereotype of the Jewish rabble. It is worth examining the efflorescence of these representations, these 'Jew' Kembles, in turn.

As befits an age of grand spectatorial theatre, John Philip Kemble was an actor of striking appearance, in possession of a tall, slender, and angular physique. This classical figure was noted by contemporaries, and extended (notably for our purposes) to his portrait. As Charles Shattuck writes, Kemble's admirers considered his narrow nose so 'majestic' that it reminded them 'of the profiles of Roman emperors preserved on ancient coins'. ${ }^{x l v i}$ In a parody of this rhetoric and in combination with his much reprised turn as Coriolanus, a noted opponent of the plebeian mob, medals minted by OPs had Kemble performing these very roles. This dynamic chimes with our central concern, for not only was Kemble a man of striking presence but his facial physiognomy was striking. Moreover his most distinctive feature was his nose, and that nose possessed a profile not dissimilar to those found in metropolitan stereotypes of the London's urban Jewish community. A number of satirical prints, such as KING JOHN and JOHN BULL and IS THIS A RATTLE WHICH I SEE BEFORE ME? [Figure 5], hardly caricature Kemble and instead depict him with few differences from his portrait sittings. This precision need not problematise our reading, our insistence on slippage, for caricature is but 
one tool in the armoury of a graphic satirist and likeness is just as powerful. And it is the latter which during the OP conflict could propel Kemble, as Kemble-cum-Mendoza, from stage to pit, from ringleader of the 'New Price' resistance 'on high' to ringleader on the ground: his likeness to Jewish physiognomy was sufficient to carry meaning.

If Kemble-cum-Mendoza rests on slippery and allusive foundations then so too does Kemble's supposed membership to the 'Jewish Rabble'. These connections are further complicated by prints such as KINGS PLACE \& CHANDOS STREET [Figure 6] where Kemble wears both cross and rosary. Should these adornments and his theatrical tyranny fail to make his supposed Catholicism explicit, he is tossed by bawds in an allusion to the punishment Sancho Pança perpetually endured. Yet crucially, making Kemble Catholic did not prevent satirists from making Kemble simultaneously Jewish. In the aforementioned mock handbill Kemble is already Catholic before he 'becomes' Jewish, and in KINGS PLACE \& CHANDOS STREET Cruikshank subtly, if strikingly, uses physiognomic parallels to connect Kemble with the Jewish pugilist on the extreme right who sneaks up behind John Bull stating 'Vat Mr Bull I cot you'. That this allusion is based on physical signifiers does not mean the signifier is purely racial. Jewishness, as Roxann Wheeler has argued, was one of a number of ethno-religious types drawn upon to define character in Georgian discourse. Indeed by entering into dialogue with Jewish communities whilst simultaneously calling for Catholic relief, Protestant dissenters such as Joseph Priestley allowed commentators to collapse nonAnglicans into a cabal of anti-types. Moreover Napoleon's calling of the Grand Sanhedrin in 1807 gave that cabal potentially pan-European currency. Thus anti-semitism could be as much religious as racial, and as the former was personal and transferable it was possible with this discourse, as Isaac Land notes, that 'the "Jew" label was applied indiscriminately to non-Jews who exhibited allegedly Jewish behaviours [...] Such a person must "be" a Jew'. What this suggests is that if we put aside assumptions that Jewishness was a purely racial signifier and 
accept that it was also a signifier of character, such blurring of ethno-religious types within representations of John Philip Kemble become less problematic.

Isaac and George Cruikshank's six-part THE STROLLERS PROGRESS, published in November 1809 by Thomas Tegg, provides a striking example of this discourse. Although the Progress explicitly charts Kemble's rise to becoming a crypto-Catholic agent of the devil, its narrative is also bound together by quasi-biblical assumptions about the urban Jew. The series begins within a chaotic 'Punch and Judy' show which the Cruikshanks project onto Kemble's childhood [Figure 7]. ${ }^{\text {xlvii }}$ The scene is defined by physical, sartorial, sexual, and behavioural disarray. These in turn intertwine with the representation of religion central to the design. The young 'Black Jack'xlviii is blessed by his mother who holds in her right hand a cross. Yet the hooked nose distinctive to the family, though here explicitly connected to a pantomimish physiognomy, clearly resembles those common in stereotypes of Jewish people.

This allusion takes on fuller meaning in the prints that follow. The second plate, for example, communicates Kemble's supposedly 'Jewish' character through a combination of textual and graphic cues which interact through the subtitle of the design - 'Blackjack not liking to be a Popish Priest returns from Douay in a state of Beggary \& rages is releived [sic] by the poor strollers at Brecknock' [Figure 8]. ${ }^{\text {xlix }}$ Kemble ('Blackjack') is now a man, and has chosen to leave his father' influence (the 'Popish Priest') to seek relief from a group of travelling actors ('poor strollers') in Brecon ('Brecknock'), the birthplace of John's younger brother Charles. ${ }^{1}$ Immediately the blurring of religious identity is foregrounded, for Kemble retains the Catholicism of his family whilst consciously obscuring from view his distinctive, 'racially' identifiable nose. Kemble's affectatious posture, which gives full exposure to his ostentatious (and hence hardly inexpensive) cross and rosary, marks him out as a dangerous lying schemer, an 'intrinsically wily and despotic' Catholic reminiscent of 'foreign intrigue'. li 
His beggary is compared with a rendition of Gay's Beggars Opera (1728) set, according to a bill posted upon the barn wall, to entertain the locals that evening. Given the incoherent and undignified attire of the actors due to perform, the show will presumably be no naturalised anti-opera in the spirit of Gay's script, a reading which interacts with the figure of Kemble who, ragged and dispossessed, is constructed through the image of the wandering Jew: another non-naturalised figure.

Much like the 'hero' of any Georgian progress, each plate sees Kemble-as-wanderer present a new state or form. Whereas previously Kemble was beggarly, in plate three he is miserly and raises a flail to a washerwomen who, we are told, 'refused to give him his shirt till he had settled the immense sum of 15 Pence.!!!'. Significantly the room contains pointed allusions to play narratives, such as George Farquhar's tale of avarice The Beaux's Strategem (1707) and Molière's Les Fourberies de Scapin (1671), the latter a farce noted for including a rakish, thieving, cowardly, and hook-nosed conman.

In plate four the absurdity of Kemble swearing an oath to King and country is foregrounded [Figure 9]. ${ }^{\text {lii }}$ Here the Cruikshank's interact directly with the Catholic question, however they also allude back to the Jew Bill controversy of 1753, where fears of Jewishcum-foreign naturalisation, with the implicit threat to 'the comprehensiveness of the sacramental test' (and hence the position of the established Church), were foregrounded. ${ }^{\text {liii }}$ At this time, Felsenstein notes, 'the notorious distich "No Jews! No wooden shoes"' repeated in opposition rhetoric throughout the ensuing pamphlet war blended: 'Contemporary prejudice against the Jews with periodic fears of French invasion and a consequent reinstatement of Catholicism. ${ }^{\text {liv }}$ This collapse of national stereotypes into a single threat was, as we have seen, no isolated incident of English paranoia. ${ }^{\text {lv }}$

Plate five contains no symbolic references to Jewishness [Figure 10]. ${ }^{\text {lvi }}$ However the subtitle 'after playing at soldiers about six weeks' clearly refers to the Jewish phase of the 
conflict, the exaggerated length once more extending its temporal significance. By neglecting to depict the theatre at all, it is the retrospective narration evident in plates one to five which is the central concern of the Progress. And this narration is brought sharply into focus by the abstract and forward looking plate 6, where a cacophony of phrases ('New Prices', 'PRIVATE BOXES', 'Pigeon Holes', 'hired Ruffians', 'DUTCH SAM', 'old prices', 'OP') and symbols (rattles, horns, pamphlets, 'The Key') ${ }^{\text {lvii }}$ associated with the OP war adorn Kemble, his steed and the detritus left in their wake as they gallop along the 'Road to Ruin' [Figure 11]: :viii a trajectory towards 'Ruin' explained, contextualised, and rendered inevitable by the 'historical' narration of plates one to five.

This essay has argued that satirical prints produced in response to the public reaction to the Jewish phase of the OP War consciously used motifs which drew upon urban stereotypes of Jewishness to construct a retrospective narrative of the OP war. With Kemble rhetorically 'a Jew', the Cruikshank-Tegg Progress not only retrospectively exaggerated the temporal length of this phase of the riots forwards, but also presented a narrative of Jewish conspiracy which predated the OP war, predated Kemble's involvement with Covent Garden theatre and predated even his arrival in London. In addition to flattening the temporality of this perceived conspiracy, the Progress exaggerated its spatial dimensions - taking print customers beyond Covent Garden theatre and across both the city and the country. The OP war was, then, much more than a protest restricted to theatrical concerns in both how it was reported and how it was experienced. By continuing to make reference to Kemble's alleged collusion with Jewish communities alongside his other 'sins' against the OPs, the metropolitan press reveal to us the continued significance into the early-nineteenth century of Jewishness as a foil against which British identity and custom were constructed, as a conduit through which live controversies could be imagined. That this foil was loose, unstable and at times tenuous suited the playful 
nature of those who protested in and outside of Covent Garden theatre during the Autumn of 1809, not least the ever mischievous caricaturists who collectively waded in on the side of Old Prices and in opposition to the supposed racial conspiracy led by John Philip Kemble.

\footnotetext{
${ }^{\mathrm{i}}$ I would like to thank Grayson Ditchfield for his comments on an early draft of this essay and the editors and reviewers for their insight, feedback and encouragement.
}

${ }^{\text {ii }}$ Marc Baer, Theatre and disorder in late Georgian London (Oxford, 1992). Baer's history of the Old Price war is an indispensable guide to the conflict.

iii Exceptions being 23 September to 4 October (when the theatre was closed whilst a report on the theatre's finances was produced), 25 October (when Covent Garden theatre hosted a lavish party to celebrate the Royal Jubilee) and Sundays (when the theatre was closed). Although the riots petered out by late-December, official conciliation (which included the reinstatement of old prices and the promise from the management to remove the private boxes) was not achieved until January 1810.

${ }^{\text {iv }}$ Heather McPherson, 'Theatrical riots and cultural politics in eighteenth-century London', Eighteenth Century: theory and interpretation, 43:3 (Fall 2002), 236-53.

${ }^{\mathrm{v}}$ A framework for conceptualising riot successfully ventured by Robert Poole in 'The March to Peterloo: Politics and Festivity in Late Georgian England', Past and Present 192:1 (2006), 109-153.

${ }^{\text {vi }}$ With the exception of the staunchly pro-management Morning Post.

vii Hannah Barker's model of newspapers as commercial entities is useful here, helping to explain why newspapers carried varied, opposing and often wholly contradictory opinions on the OP war within their pages. In sum, the discursive business of newspaper proprietors (that beyond their role as forums for advertisements) was less to pursue a polemical line and more to appeal to potential readers and purchasers of their newspapers. See Hannah Barker, Newspapers, Politics and English Society, 1695-1855 (Harlow: Longman, 2000). It is worth noting also that pamphleteers, part of London's literary print genre, were moved to comment, pontificate and make comic light of the riots. They too, as the historian of science Adrian Johns has broadly outlined, functioned within a commercial rather than individualist or artistic environment. In sum their producers, as is the case for newspaper vendors, would have aimed their content at a likely purchaser, and hence the content therein was driven by this consideration. Adrian Johns, The Nature of the Book: Print and Knowledge in the Making (Chicago: University of Chicago Press, 1998).

viii The Morning Chronicle, 19 October 1809, 3.

${ }^{\text {ix }}$ As the hired pugilists were described by 'A FRIEND OF NEW PRICES' in a letter reporting the events he witnessed on 6 October; The Times, 9 October 1809, 2.

${ }^{\mathrm{x}}$ The Morning Chronicle, 12 October 1809, 3.

${ }^{\mathrm{xi}}$ The Morning Chronicle, 14 October 1809, 3.

${ }^{\text {xii }}$ The Times, 20 October 1809, 2.

xiii The Morning Chronicle, 16 October 1809, 3. 
${ }^{\text {xiv }}$ Though, of course, at this time the Jewish phase of the riots may have seemed lengthy in the context of the ongoing riots as a whole.

${ }^{\mathrm{xv}}$ The Morning Chronicle, 20 October 1809, 3.

${ }^{\text {xvi }}$ The Times, 23 October 1809, 3.

xvii The Times, 1 November 1809, 2.

xviii The Times, 23 November 1809, 2.

${ }^{\text {xix }}$ The act effectively cast actors as vagrants and thus offered an easy shorthand for discrediting the acting profession as a whole.

${ }^{\mathrm{xx}}$ Quote from advertisement in The Morning Chronicle, 14 October 1809, 1. Further advertisements appeared in the same publication on October $17^{\text {th }}$ and October $20^{\text {th }}$.

${ }^{x x i}$ The Morning Chronicle, 18 October 1809, 3.

xxii The Times, 3 November 1809, 2.

xxiii The Times, 8 November 1809, 2.

${ }^{\text {xxiv }}$ The Times, 21 October 1809, 2.

${ }^{\mathrm{xxv}}$ The Morning Chronicle, 19 October 1809, 3.

${ }^{x x v i}$ The Morning Chronicle, 20 October 1809, 3. This song clear parodies Act 5 Scene 3 of Shakespeare's Richard III where the protagonist reads a paper his is delivering to Norfolk which states: 'Jockey of Norfolk, be not too bold, | For Dickon thy master is bought and sold'.

xxvii The Times, 12 November 1809, 3.

${ }^{\text {xxviii }}$ For an excellent summary of the debates in the run up to the 1829 Roman Catholic Relief Act see Boyd Hilton, A Mad, Bad, and Dangerous People?: England, 1783-1846 (Oxford: Oxford University Press, 2006), 384-397.

${ }^{\text {xxix }}$ The Examiner, 15 October 1809, 3.

${ }^{x x x}$ Matthew Biberman, Masculinity, Anti-Semitism and Early Modern English Literature: From the Satanic to the Effeminate Jew (Aldershot: Ashgate, 2004), Frank Felsenstein, Anti-Semitic Stereotypes: A Paradigm of Otherness in English Popular Culture, 1660-1830 (Baltimore, MD: Johns Hopkins University Press, 1995), Dana Rabin, 'The Jew Bill of 1753: Masculinity, Virility, and the Nation', Eighteenth-Century Studies 39:2 (2006), 157-171, Michael Ragussis, Theatrical nation: Jews and other outlandish Englishmen in Georgian Britain (Philadelphia: University of Pennsylvania Press, 2010), Jerry White, London In The Eighteenth Century: A Great and Monstrous Thing (London: Bodley Head, 2012), 145-152.

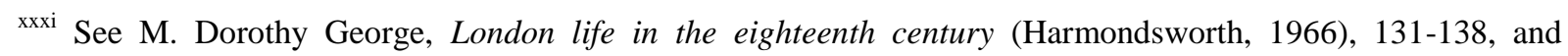
William J. Fishman, 'Allies in the Promised Land: Reflections on the Irish and Jews in the East End', in Anne J. Kershen (ed.), London: the promised land? (Aldershot, 1997), 38-49.

xxxii Such irrational constructions are a notable feature of, for example, the 1753 Jewish Naturalisation Act controversy. See Dana Rabin, 'The Jew Bill of 1753: Masculinity, Virility, and the Nation', Eighteenth-Century Studies 39:2 (2006), 157-171.

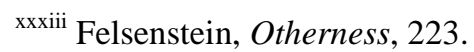


${ }^{\text {xxxiv }}$ Discourses are of course always in transition. Nonetheless Felsenstein offers a compelling argument that the early-nineteenth century was a crucial turning point in the British use of the Jewish stereotypes; Felsenstein, Otherness, 238.

${ }^{\operatorname{xxx}}$ A useful if fundamentally anachronistic term, the word 'stereotype' was coined by Walter Lippman in his seminal Public Opinion (New York, 1922).

${ }^{x x x v i}$ See Felsenstein, Otherness, 232.

xxxvii White, London, 146-147.

xxxviii Isaac Cruikshank, EASIER to say, than to $\underline{d o}$ ! (14 April 1803, Thomas Williamson) [British Museum Caricatures 9979 (hereafter BM)].

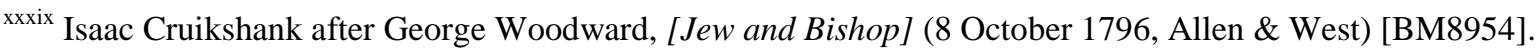

${ }^{\mathrm{xl}}$ Isaac Cruikshank, SOLOMON in all his GLORY!! (26 March 1807, Thomas Tegg) [BM10908]

${ }^{x l i}$ For the utility of the term, see Matthew Biberman, Masculinity, Anti-Semitism and Early Modern English Literature: From the Satanic to the Effeminate Jew (Ashgate, 2004).

xlii Caledonian Mercury (Edinburgh, Scotland), 21 October 1809.

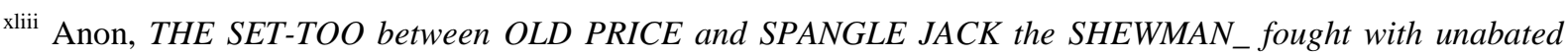
vigour for nine round \& yet undecided Oct 6 (October 1809, Elizabeth Walker) [BM11420]. The classic accounts of so-called 'Golden Age' graphic satire are M. Dorothy George, Hogarth to Cruikshank: social change in graphic satire (London, 1967), Diana Donald, The Age of Caricature: Satirical Prints in the Reign of George III (New Haven, 1996), and V. A. C. Gatrell, City of laughter: sex and satire in eighteenth-century London (London, 2006). Though offering competing interpretations on the medium during their given periods, all subscribe broadly speaking to an artist/art-work centric vision of the trade seen in works such as Draper Hill, Mr. Gillray: the Caricaturist, a Biography (London, 1965). For a biographical portrait more sensitive to the realities of production, consumption, and environment see Robert L. Patten, George Cruikshank's Life, Times, And Art, 2 vols. (London, 1992). For studies which disentangle the notion of 'popular' see Sheila O'Connell, The Popular Print In England, 1550-1850 (British Museum, 1999), and Brain Maidment, Comedy, Caricature and the Social Order 1820-1850 (Manchester: Manchester University Press, 2013). Todd Porterfield (ed.), The Efflorescence of Caricature: 1759-1838 (London, 2011) attempts to break free of the orthodoxies described here and achieves this with varying levels of success, see James Baker, Reviews in History, 'review of The Efflorescence of Caricature: 1759-1838' (review 1084) URL:http://www.history.ac.uk/reviews/review/1084.

xliv The minimum turnaround for a copper plate etched satirical print, from design to point of sale, was three to four days.

${ }^{x l v}$ The Times, 7 October 1809, 2.

xlvi John Philip Kemble promptbooks, 11 vols., ed. Charles H. Shattuck (Charlottesville, 1974), 1, ix.

${ }^{\text {xlvii }}$ [Isaac and George] Cruikshank, The Strollers Progress Pte 1 (November 1809, Thomas Tegg) [Edward Bell Krumbhaar, Isaac Cruikshank: a catalogue raisonne with a sketch of his life and work (Philadelphia, 1966). 1161 (hereafter Krumbhaar)].

${ }^{x l v i i i}$ A nickname deploying the legend of the 'Black Prince' to mock the anti-chivalry of Kemble.

${ }^{x l i x}$ [Isaac and George] Cruikshank, The Strollers Progress Pte 2 (November 1809, Thomas Tegg) [BM11426]

${ }^{1}$ John Russell Stephens, 'Kemble, Charles (1775-1854)', ODNB. 


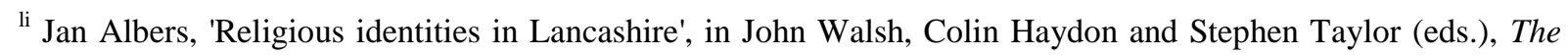
Church of England c. 1689 - c. 1833: From Toleration to Tractarianism (Cambridge, 1993), 325, 324. The Cruikshanks also make a visual quotation here to Kemble's posture in James Gillray's earlier Theatrical Mendicants, relieved (Hannah Humphrey, 15 January 1809) [BM11413].

lii [Isaac and George] Cruikshank, The Strollers Progress Pte 4 (November 1809, Thomas Tegg) [Krumbhaar 1164].

liii Thomas W. Perry, Public Opinion, Propaganda, and Politics in Eighteenth-Century England: A Study of the Jew Bill of 1753 (Harvard University Press, 1962), 178-80, quote 179.

${ }^{\text {liv }}$ Felsenstein, Otherness, 193-4.

${ }^{\text {Iv }}$ See for example the trial of trial of Eliza Iredale in the Old Bailey Proceedings, February 1810 (t18100221106), where a debate over oaths descends into a conflation (by the judiciary) of Judaism with other non-Christian heresies.

lvi [Isaac and George] Cruikshank, The Strollers Progress Pte 5 (November 1809, Thomas Tegg) [BM11428].

Ivii See KINGS PLACE \& CHANDOS STREET above.

lviii A playful allusion to Thomas Holcroft's The Road to Ruin which played at Covent Garden Theatre during 1792. [Isaac and George] Cruikshank, The Strollers Progress Pte 6 (November 1809, Thomas Tegg) [Krumbhaar 1166]. 